\title{
From Power over Creation to the Power of Creation: Cornelius Castoriadis on Democratic Cultural Creation and the Case of Hollywood
}

\begin{abstract}
This article is a critical investigation and application of the aesthetic theory of Cornelius Castoriadis, one of the most important 20th-century theorists of radical democracy. We outline Castoriadis's thoughts on autonomy, the social-historical nature of Being, and creation-key elements that inform his model of democratic culture. We then develop a Castoriadian critique of culture produced by capitalist institutions. By also drawing on the political economic thought of Thorstein Veblen, Jonathan Nitzan and Shimshon Bichler, our critique focuses on one sector of contemporary culture: Hollywood film. We show how Hollywood, as a business enterprise, uses techniques of sabotage and capitalization to control and occult the social-historical nature of creation. Lastly, by way of conclusion, we gesture toward a mode of artistic production that is able to affirm the democratic values that organize Castoriadis's thought.

RÉSUMÉ

Cet article s'attache à analyser de manière critique et à analyser la théorie esthétique de Cornelius Castoriadis, un des plus importants théoriciens du XXe siècle en matière de démocratie radicale. Nous présentons les réflexions de Castoriadis à propos de l'autonomie, de la nature sociohistorique de l'Être et de la création, des éléments cruciaux informant son modèle de culture démocratique. Nous proposerons ensuite une critique castoriadienne de la culture telle que produite par les institutions capitalistes. En nous appuyant également sur la pensée économique de Thorstein Veblen, Jonathan Nitzan et Shimshon Bichler, notre critique prend pour objet un élément de la culture contemporaine : le cinéma hollywoodien. Nous montrons qu'Hollywood en tant qu'entreprise commerciale a recours aux techniques de sabotage et de capitalisation pour contrôler et dissimuler la nature sociohistorique de la création. Pour conclure, nous envisageons un nouveau mode de production artistique qui soit capable d'affirmer les valeurs démocratiques jalonnant la pensée castoriadienne.
\end{abstract}


KEYWORDS: Cornelius Castoriadis; Hollywood film industry; mass culture; democracy cultural creation; aesthetic theory; capitalism

a

In recent years, democratic theorists have shown increasing critical interest in the scholarly work of the Greek French philosopher Cornelius Castoriadis. Throughout his life, Castoriadis made significant contributions to democratic thinking in a wide variety of fields, including political theory, philosophy, psychoanalysis and economics. However, he never completed a systematic elaboration of his aesthetic theory, which exists only in germinal form in various essays on the state of contemporary culture. This article will not attempt to construct a Castoriadian aesthetic theory. Rather, it will outline certain key modes of artistic practice that can be seen to either affirm or deny Castoriadis's unique creative ontology, an effort that we hope will contribute to his wider project of individual and collective autonomy. Castoriadis is unique within 20th-century political theory in the way in which he interprets democratic practice in terms of its creative and interrogative characteristics, and in terms of its orientation to free and reflective self-alteration. This understanding of democracy provides an exemplary ground from which to reconceptualize the meaning of artistic practice and its potential relation to a wider project of autonomous human activity. In particular, by examining two case studies to varying degrees, we will argue that Castoriadis's unique attempt to theorize democratic practice in terms of the non-determined institution of form provides a unique model with which to evaluate the state of contemporary aesthetic production and reception.

\section{Castoriadis on Art and the Democratic Imaginary:The Ontological Status of Art as Radical Creation}

According to Castoriadis, the fundamental problem with all inherited ontologies is their presupposition of the ability to treat Being in terms of the mere determinacy and repetition of already existing objects, ideas and concepts. Castoriadis suggests that Being eludes all such determinative schema: "Being is abyss, or chaos, or the groundless," he writes (Castoriadis 1997b: 3). Being is a non-determinate field of irregular stratification that cannot be thought of in terms of a system of ensembles, and that therefore cannot be appropriated by means of what Castoriadis calls ensemblistic-identitary, or ensidic, logic. Ensidic logic attempts to reduce existence to "an ensemble of distinct and well-defined elements, referring to one another by means of well-determined relations" (Castoriadis 1998: 177). Any such logic must affirm a system in which all places are fixed and occupied. Movement here is simply the repetition or reorganization of the same, as Being is always being determined. True Being, however, is not determination, not production that can be causally traced back to prior determinates that form elements of a teleological process of 
development, but creation in the radical sense. It is alterity, the ex nibilo-which is not to say cum nibilo or in nibilo-emergence of "other determinations, new laws, new domains of lawfulness" (Castoriadis 1997c: 308). Being, to the extent that it is creation, is "a vis formandi (a power of formation) which is not predetermined and which superimposes on the Chaos a Cosmos, a World that is organized and ordered somehow or other" (Castoriadis $1997 \mathrm{~d}$ : 342).

For Castoriadis, the uniqueness of the specifically human being lies in the fact that the human being is Chaos, not just to the extent that it participates in Being, but also because it alone among beings is an imaginary being. ${ }^{1}$ He suggests that there is a poietic dimension to being human, to the degree to which humans are not just vis formandi, but also libido formandi: "to the potential for creation found in being in general, the human sphere adds a desire for formation" (Castoriadis 1997d: 342). This formation, this creative giving form to Chaos, is the generation of a unique world of signification that is positively cathected by social individuals. We are here in the realm of the social-historical, of society as history, and have identified its fundamental characteristic:

The perpetual self-alteration of society is its very being, which is manifested by the positing of relatively fixed and stable forms-figures and through the shattering of these forms-figures which can never be anything other than the positing-creating of other forms-figures. (Castoriadis 1998: 372)

In light of this brief discussion of the understanding of Being as creation, it is perhaps easy to anticipate what Castoriadis takes to be the significance of art: "Art, qua creation, is the opening up of a window toward the Abyss, the Groundless, the Chaos which is the ultimate essence of Being" (Castoriadis 1991a: 234). In short, art is an exemplary case of the activity of creative giving-form. Castoriadis speaks of "the ontological specificity of art as creation," to the degree that "the great work of art does not follow rules but posits new rules" (Castoriadis 1991b: 90). The existence of art as creation has generally not been recognized by philosophers of aesthetics; their situation within the traditional logos has prevented them from grasping the meaning of Being. The inability to grasp art as creation is a correlate of the inability to understand history as creation, the failure of the latter obscuring the ontological status of the former.

To understand this dynamic, we must first grasp Castoriadis's well-known distinction between autonomous and heteronomous societies. We know that society is the perpetual emergence of new forms of social existence that cannot be logically traced back to prior moments in a causal historical continuum. Castoriadis argues it is thus impossible to construct a society that terminally realizes itself in its institutional form: "There will always be a distance between society as instituting and what is, at every moment, instituted" (Castoriadis 1998:114). This gap "is one of the expressions of the creative nature of history, what prevents it from fixing itself once and for all into the 'finally found form' of social relations and of human activities" 
(Castoriadis 1998: 114). More often than not, this creative nature is occulted by an extra-social source, such as God, nature, the ancestors, the laws of history and so on. Societies marked by such occultation are heteronomous. Opposed to these are autonomous societies, which aim to make self-institution explicit. An autonomous society is "a society capable of explicitly self-instituting itself, capable therefore of putting into question its already given institutions, its already established representation of the world" (Castoriadis 1991c: 136).

What, then, can be said of art in autonomous societies? We must note that according to Castoriadis the project of autonomy emerged for the first time in ancient Greece. It is thus not surprising that perhaps the most constructive manifestation of an autonomous mode of artistic existence is revealed there in the form of Athenian tragedy. Examples of autonomy and heteronomy in art can be found when we compare two of the greatest Greek tragedians: Sophocles and Aeschylus. The distinction between Aeschylean and Sophoclean anthropogeny lies in each tragedian's relation to the recognition or non-recognition of explicit self-institution as a mode of existence. Aeschylus's anthropogeny

answers the question concerning antbroppos by turning to the source of his existence and by presenting a narrative-antbroppos is whatever he is because at some point long ago (beyond all possible empirical corroboration or disproof) something happens that surpasses our usual experience. (Castoriadis 2007a: 4-5)

Specifically, according to Aeschylus, Prometheus bestowed upon human beings those gifts that make their humanity possible. Castoriadis, though, insists that such a paradigm of passive reception is antithetical to all we know about the creative nature of human beings: "Man does not 'have' language and thought: he gave them to himself, created them for himself and taught them to himself" (Castoriadis 2007b: 26). This fact of anthroppos as self-creation is affirmed by Sophocles, who sees those capacities supposedly bestowed upon humans by Prometheus not as extrasocial, but as created by humans themselves: "He simply, clearly, and emphatically posits humanity as self-creation. Humans took nothing from the gods, and no god gave them anything. This is the spirit of the fifth century, and this is the tragedy that the Athenians chose to reward" (Castoriadis 2007a: 11). The "fundamental political significance" of tragedy lies in the fact that, as a form of cultural creation emerging in a context of autonomy, it, along with political and philosophical creation, aims not at simply covering up or imitating, but at opening and uncovering, via its affirmation of the non-determinate creative capacity of humanity (Castoriadis 1991a: 235).

What tragedy allows us to see is that Being is Chaos, the latter being represented by the lack of a positive order of Being, by humans' inability to control absolutely their actions on the world. The presumption of such control is the key manifestation of hubris, that subject of Sophoclean tragedy exceptionally expressed in Antigone. 
The characters Antigone and Creon are two opposed authorities who each attempt to assert hubristically their own complete right at the expense of all others: "Both of the principal characters in this tragedy were wrong because each had become entrenched in his or her own reasons while ignoring the other's reasons" (Castoriadis $1997 \mathrm{e}: 117)$. Antigone is the quintessential democratic tragedy because it so emphatically condemns the process of thinking alone-monos phronein-while recognizing that democracy depends on the self-limitation of individual and community. Limitation must be self-limitation precisely to the extent that Being is creation, to the extent that there exists no extra-social power capable of outlining the boundaries of our actions. Both Antigone and Creon lack the capacity for self-limitation inasmuch as they lack phronein. With phronein, the human being can affirm the social nature of politics, as he or she is capable of creatively weaving together various laws, judgments and arguments-all of which originate from social relationships. In Antigone, Sophocles uses the tragic style to show why "Antigone and Creon are incapable of this interweaving. Both of them, by equally blindly and absolutely defending one of the two principles, become bubristès and apolis" (Castoriadis 2007a: 11). Their error lies in assuming they each possess the absolute standard for action, which is capable of guiding and regulating their behaviour in the world. Indeed, it is precisely this belief in the legitimacy of these schemas of universality that marks heteronomous thinking.

\section{Art and Democratic Being}

As a political regime, democracy corresponds to the fundamental principle of autonomy, to the extent that it affirms the perpetual interrogation of the social sphere via the critical self-activity of the demos. It is the mutual presence of this interrogative dimension that makes it impossible to separate art from democracy: what both presume is that there exists no ultimate signification capable of covering over Chaos and providing a final guide or foundation for action. Unlike cultural creation in heteronomous societies, democratic cultural creation does not simply repeat or one-sidedly affirm given social norms: "In a democratic society the cultural work does not necessarily lie within a field of instituted and collectively accepted significations" (Castoriadis 1997d: 344). Such significations, rather, are called into question:

Great art is both society's window onto the chaos and the form given to this chaos... Art is a form that masks nothings. Through this form art shows the chaos indefinitely — and thereby calls back into question the established significations, up to and including the signification of human life and of the contents of this life that have been left furthest beyond discussion. (Castoriadis 1995: 100)

Here, norms and significations are generated ex nibilo. It is through the imposition of new forms that access is granted to the non-stratified and variegated modes of 
Being. Such art invokes "the exploration of ever new strata of the psyche and the social, of the visible and the audible, so that it might, in and through this exploration, and it its own unique way, give form to the Chaos" (Castoriadis 1997d: 345).

It needs to be stressed, however, that such cultural creation should not be singularly identified with the productive work of the artist. The creator of an artwork is implicated in a generalized cultural environment positively cathected by all social individuals. Castoriadis defines culture as all of that which refers us to the imaginary dimension of social human being:

We shall call culture all that, in the public domain of a society, goes beyond that which is simply instrumental in the operation of that society and all that introduces an invisible - or better, an unperceivable - dimension invested or "cathected" in a positive way by the individuals of that society. (Castoriadis 1997d: 339)

Castoriadis elaborates on the nature of the relation between the negative moment of cultural interruption and the positive one of cultural socialization:

The great work of art creates a shock-a shock which is an awakening. The intensity and greatness of the work of art are absolutely inseparable from this shaking up, this vacillation of the established, instituted meaning of things and life. But this vacillation can only take place if there is a positive sense in the lives of the artist and the public as well, a positive meaning not of life in general, but in what they are doing in life. (Castoriadis 1991a: 229)

We are thus confronted with a seeming contradiction: cultural creation aims at the generation of new social significations, but such creation is only possible to the extent that the producers and receivers of such creation find themselves in a coherent society of which they are already a fragment via their positive cultural socialization - that is, their cathexis of already-existing cultural norms. In a social environment marked by the presence of autonomy, this contradiction is sublated as an organizing value, for only in autonomous societies is the very signification of unlimited interrogation affirmed as an organizing principle.

In other words, the myth of the isolated and atomic artist is precisely that: a myth. For Castoriadis, true individualism depends on positive socialization:

We truly become individuals only by dedication to something other than our individual existence. And if this other thing exists only for us, or for no one-which is the same thing-we have not left mere individual existence, we are simply mad. Vermeer painted in order to paint-and that means, in order to bring into being something for someone or some ones for whom this thing would be painting. (Castoriadis 1993a: 311)

We are referred here to the critical issue of artistic reception. Although adamant about the need to maintain a distinction between the creation and the reception of 
a work of art, Castoriadis nevertheless claims that the latter is equally as creative as the former:

The individuated individual creates a meaning for its life by participating in significations that its society creates, by participating in their creation, either as "author" or as (public) "receiver" of these significations. And I have always insisted on the fact that the genuine 'reception' of a new work is just as creative as the creation thereof. (Castoriadis 1995: 98-99)

Democratic art is impossible without re-creative participation on the part of the public:

Above all, the public is caught up in the new meaning of the work-and it can be so caught up only because, despite inertia, delays, resistances, and reactions, this public is itself creative. The reception of a great new work is never and can never be a matter of mere passive acceptance; it is always recreation. (Castoriadis 1997d: 347)

Needless to say, such participation depends on a positive socialization that affirms the values of autonomy. Its content can be revealed, for example, in those societies in which art has transcended its status as mere end-in-itself in order to express the mode of being of the social community:

The Greeks or the people of the Renaissance did not live for art, but they put great value into their art because they recognized themselves and their problems in it. Their whole life had a meaning that was expressed in its highest forms in this artistic creation. (Castoriadis 1993b: 108)

For Castoriadis, an autonomous society is not one in which every individual is somehow or other transformed into a great artist, but rather one in which all individuals are open to social-historical creation, one mode of which is affirmed via their creative reception of artistic creation. It is precisely such reception, however, that is more and more closed off in contemporary liberal-democratic-or what Castoriadis calls liberal-oligarchic-societies. According to Castoriadis, what has historically defined modern societies is the existence and interrelationship of two primary significations, one affirming the project of collective and individual autonomy and one affirming the unlimited expansion of the rational mastery of the natural world. Increasingly, however, those substantive values associated with the project of autonomy are being eclipsed and replaced by those merely formal values associated with rational mastery, which can be identified with the capitalist value of consumption for the sake of consumption. The key question with respect to artistic production in such a climate is: "Can creation of works occur in a society that does not believe in anything, that does not truly and unconditionally value anything?" (Castoriadis 1993a: 306). If the work of art is to maintain its critical function, it must exist in a positive relation to the values of society: 
The shock the work provokes is an awakening. Its intensity and its grandeur are inseparable from this shaking up, this vacillation of established meaning. There can be such a shake-up, such a vacillation, if and only if this meaning is well-established, if the values are strongly held and lived as such. (Castoriadis 1993a: 306)

At the same time as the degradation of signification neutralizes the reception of aesthetic shock, so too does the positive relation between the artist and the public begin to dissolve. If in democratic contexts the genius of the artist is inseparable from the genius of the demos, both of which participate in a social-historical mode of being that contains the cultural sphere, with the rise of capitalism we see the development of a specifically bourgeois culture, marked above all else by a nondemocratic rupture between this culture and society. The initial consequence of this rupture was the emergence of an artistic avant-garde:

The result was the appearance, for the first time in history, of the phenomenon of the avant-garde and of an artist who is "misunderstood," not "by accident" but of necessity. For, the artist was reduced at that time to the following dilemma: to be bought by the bourgeois of the Third Republic - to become an official pompier-style artist —or to follow his/her own genius and to sell, if lucky, a few canvases for five or six francs. (Castoriadis 1995: 109)

In such an environment it is no longer possible for the artist to find nourishment in his or her public, nor for the public to locate itself in the work of the artist. The logical result of a social dynamic characterized by the gradual eclipsing of positive social values by the formal pursuit of status, wealth, power and so on, is the reduction of artistic practice to either the simple reproduction of past works or empty innovation for its own sake.

\section{Mass Culture and Capital}

To concretize the connection Castoriadis makes between a political project of autonomy and cultural creation, we continue from the example of the artistic avant-garde, thinking more deeply about the current organization of artistic practice. Because the making/doing of individuals is currently oriented "toward the antagonistic maximization of consumption, of power, of status, and of prestige," and because "society is enslaved to the imaginary signification of unlimited expansion of 'rational' mastery," Castoriadis suggests the "institution of an autonomous society would require the destruction of the 'values' presently orienting individual and social making/doing" (1993a: 303).

An essential characteristic of contemporary society is that many of its cultural objects are mass-produced by capitalist firms. Could a capitalist cultural institution ever embrace autonomy, as defined by Castoriadis? To answer this question, let us present our first case study: major film distribution in Hollywood, a dominant 
cultural institution that essentially comprises six large firms. ${ }^{2}$ To Castoriadis, cinema stands as one of the "great creations of the first quarter of the twentieth century" (1993a: 306). Presumably, such a statement suggests two things. First, as art, film can open up a window toward the Abyss. Second, as a product of radical imagination, a film can make "something be" by creating "another eidos" (Castoriadis 1998: 290,197). Thus, it is possible for a film to be other than the films that came before it, just as The Divine Comedy is not different from but "other than the Odyssey" (Castoriadis 1998: 195).

However, we argue that Hollywood, as a cultural institution, cannot embrace autonomy because it must control social signification and radical creation in order to capitalize the social foundations of culture. Hollywood can certainly produce culture, and we may catch glimpses of autonomy at certain moments, such as during the period of the American New Wave, or what is sometimes called "New Hollywood." Yet Hollywood cinema, overall, bears the markings of heteronomy to the extent that the logic of capital is antithetical to the openness of radical creation. Just as Plato monopolized the term poiesis by reducing all creation to imitation (mimesis), the major film-entertainment firms of Hollywood reduce filmmaking to a "coherent set of already produced means (instruments) in which this power is embodied" (Castoriadis 1998: 195).

To substantiate this Castoriadian critique of Hollywood, it would be helpful to incorporate a political economy approach. The capital-as-power theory, first developed by Shimshon Bichler and Jonathan Nitzan (2009), is useful support. ${ }^{3}$ With a clear affinity for Castoriadis's social theory, Nitzan and Bichler offer a political economic method that can deepen our meditations on culture in several ways. First, by building from Castoriadis's (1984a) critique of Karl Marx's interpretation of Aristotle, Nitzan and Bichler argue that equivalence in exchange in capitalism is not rooted "in the material sphere of consumption and production, but in the broader social-legal-historical institutions of society" (2009: 148). Second, Nitzan and Bichler argue that a concept of capital must go to the roots of the capitalist imaginary, which, in parallel to Castoriadis's critique of Marxism, is much more than an autonomous, isolatable "economic" sphere. Third, the capital-as-power approach allows us to conceptualize the ownership and management of modern cultural production as an institutional mechanism of power, not productivity. While this presentation of power over creation has clear theoretical lineage in the history of political economic theory, ${ }^{4}$ especially Marx's (1990) analysis of power in the division of labour in manufacture, it has an even more explicit connection to Castoriadis. With the means to control and direct the ends of social creativity in cinema, capitalists are, in the eyes of Nitzan and Bichler, what Castoriadis would call an "explicit power." Capitalist power, like legislative, executive and judicial power, is an orientation to historical time. It is 
rooted in the necessity [for the explicit power] to decide what is and is not to be done with respect to the more or less explicit ends which are the objects of the push and drive of the society considered. (Castoriadis 1991d: 155)

Weaving Nitzan and Bichler into the analysis of Castoriadis and culture can help explain how the profits of Hollywood depend on its ability to control both the relationship between filmmakers and their audience, and the relationship between radical creation and already-accepted significations. More substantially, the capitalas-power approach offers two relevant concepts: strategic sabotage and capitalization. These concepts explain why the possibility of democratic culture must be repressed if a capitalist firm is to profit from cultural production.

\section{Strategic Sabotage}

To show how democratic culture is repressed for the sake of the accumulation of capital, we must first outline how limitation in Hollywood is not the self-limitation of an artist. The power relationship between capital and artistic creation can be described with what is the springboard for Nitzan and Bichler's theory: capital as defined by Thorstein Veblen. For Veblen (2006a), capital belongs to the realm of business and not the realm of industry. The ways and means of industrial production may or may not be beneficial, pleasurable or useful; but what is or is not beneficial, pleasurable or useful about material production depends on which cultural and political ideas hold court at a certain moment in time (Veblen 2006a: 324-51). As D.T. Cochrane notes, there is similarity between Veblen's concept of industry and Castoriadis's theory of social signification (2011: 107). The worth of industry to a community is determined by social significations that define, in the words of Castoriadis, what "is and is not, what is relevant and what is not, [and] the weight, the value... of what is relevant" (1998: 234).

On the other hand, the nominal price of an asset, for Veblen, has little to do with the material magnitude of productivity, because industry is not the "real" essence of capital. A stock of technology, knowledge, energy or human creativity says nothing about how its material benefits are distributed among members of a community. Capital "is a pecuniary concept, not a technological one; a concept of business, not of industry" (Veblen 2006b: 359). Veblen does not deny the influences of technological efficiency and the sweat of labour on the success of business-indeed, production is a necessary condition. But he suggests that capitalization does not measure the level of technology or the efficiency of the production process; it measures the ability to make a profit (Veblen 2006b).

By using the writings of Veblen to supersede the respective frameworks of neo-classical economics and Marxist political economy, Nitzan and Bichler argue that prices and earnings do not reflect "productivity per se," but "the control of productivity 
for capitalist ends" (2009: 223). In capitalism, control and power stand outside of industry (Nitzan and Bichler 2000: 78). The owner derives an income from his or her legal rights to sabotage industry, to "keep the work out of the hands of the workmen and the product out of the market" (Veblen 2004: 66). Nitzan and Bichler clarify that sabotage through the rights of private ownership need not be exercised: "What matters is the right to exclude and the ability to exact terms for not exercising that right" (2009: 228). Strategy, in this case, is significant, as too little sabotage can be just as disastrous for pecuniary earnings as too much sabotage. Moreover, the strategies of business sabotage are always undertaken in reference to society at large, the counterweight of capitalist power. Strategic sabotage involves pushing the limits of what societies, as a whole, will bear with respect to poverty, unemployment, crime and other symptoms of inflation and income distribution (Bichler and Nitzan 2012; 2014).

The details of any specific business-industry relationship depend on the types of industry being controlled by business. The sabotage of art differs in its details from the sabotage of the production of cars. And within the realm of art, the sabotage of film differs from that of music. ${ }^{5}$ Yet, in order to exist, the film business must find its own means of sabotage, as other sectors in capitalism do, and withhold the products of an industrial process:

The only way...spending [on productive capacity] can become profit-yielding investment is if others are prohibited from freely utilizing its outcome. In this sense, capitalist investment-regardless of how "productive" it may appear or how much growth it seems to "generate"-remains what it always was: an act of limitation. (Nitzan and Bichler 2009: 233)

To have any price attached to a film, there must be a claim of ownership that is effective. A claim of ownership must mean something to the person or group that holds it. A particular film property must be embedded in a social imaginary of private property, as the ability to exclude and keep what is mine separate from what is yours depends on the institution of a certain nomos. Abstracted from the social structures that support them, claims of ownership are useless pieces of paper or empty entitlements. The real ability to keep everyone else's hands off of your claim is nothing but social power that is expressed through the state, laws, the courts, the police and an established culture of private property and exclusive rights (Nitzan and Bichler 2009: 228).

While the absentee owner-investor may know next to nothing about how a film is made (as that is a matter of industrial technique), he or she may nonetheless be interested in how the material properties of a film will serve capitalist investment. For instance, relevant to the film business is the indivisibility of the film image. Indivisibility refers to how one person's consumption of a film does not exhaust the physical capacity for someone else to watch it in tandem (Sedgwick and Pokorny 2005: 13). The indivisibility of a film is not infinite: there are technological and 
physical limits to how many people can watch the same image on the same screen (although the Internet is breaking all sorts of spatial barriers to how people can access motion pictures). However, unlike the physical properties of a car, which excludes potential passengers with a rigid steel frame, the light of a film image is not, on its own, an effective method of regulating how many people can come together and watch it collectively.

Walter Benjamin (1968) saw in mechanical reproduction an opportunity for the demos to reject ritual and any heteronomous reverence for the aura of tradition, yet the modern film business has constructed another reality. For the film business at large, the film image is an industrial technology that, in order for business enterprise to "charge what the traffic will bear," needs to be sabotaged and kept at so-called "reasonable" levels. Thus, from the earliest days of film, the business side needed means of exclusion that could manage this so-called problem of indivisibility. For instance, from the 1900s to the late 1910s, the major power to staunch the possibility of indiscriminate exhibition-indiscriminate according to business principles - was the Motion Picture Patent Company, the Edison Trust. Spearheaded by Thomas Edison himself, the Edison Trust leveraged its pool of patents over film technology to set prices. The trust also attempted to control how many movies were made, what types of movies were made and where movies were shown (Litman 1998: 10; Wu 2010: 64).

Another example of controlling indivisibility, this time from the sphere of law, concerns the institution of socially acceptable exhibition. The issue for vested interests has been to ensure that the evolution of film exhibition, through the inventions of VHS, DVD and Blu-ray Disc, does not undermine the ability for business to strategically sabotage the promise of open-ended viewing outside of institutionally sanctioned spaces. To guarantee that portable film technology (an industrial capacity) does not engender a multitude of cultural public spheres, the acceptable "public performance" of a Hollywood film is a right that is purchased from the owner of the copyright. On the basis of copyright law, film screenings at "bars, restaurants, private clubs, prisons, lodges, factories, summer camps, public libraries, daycare facilities, parks and recreation departments, churches and non-classroom use at schools and universities," all come at the price of a "public performance license" (Motion Picture Association of America 2011).

With this brief outline of strategic sabotage we can start to think of situations that would be beneficial to the art of film but nightmarish for the film business. From the point of view of aesthetics and democratic principles, free public performances and a culture of open sharing could energize the world of cinema. Public access to motion pictures, for instance, could enable a demos to critically engage with the creation of cinema. An engaged assembly of moviegoers could in turn enliven artists in the film industry who know that the principle of producing "cheaply and interestingly made distractions" has nothing to do with aesthetics and everything 
to do with profit (Bloch 1988: 27). Could absentee owners of film property ever embrace these alternative, democratic principles? In the words of Theodor Adorno, the owners of contemporary culture are all too happy for the relationship between producer and consumer to be "functionalized, extended and reproduced by business" (2004: 190). The prices and profits of Hollywood depend on the ability of its firms to arbitrate the social relations of cinema.

\section{Capitalization and Social Signification}

And what can we say more specifically about the creativity of filmmaking? If Hollywood has a vested interest in the quantity of film releases, does sabotage also leave its mark on the content and style of modern filmmaking? What would be the purpose of specifically sabotaging the creative process of filmmaking? These questions are worth pursuing because the loosening and tightening of power over the industrial art of filmmaking has visibly affected the always-mediated relationship between Hollywood filmmakers and their audiences. For example, a glimmer of positive cultural socialization, as described by Castoriadis, is visible in the creativity of what many scholars call "New Hollywood," a period from roughly 1968 to 1977. By acquiring relatively autonomous creative control—from project approval to final cut-New Hollywood filmmakers such as Hal Ashby, Robert Altman, Peter Bogdonovich, John Cassavetes, Francis Ford Coppola, William Friedkin, Sidney Lumet, Arthur Penn and Bob Rafelson were able to search for new cinematic styles that would reignite the participation of audiences.

New Hollywood cinema appealed to an active, thoughtful audience because it used — as David Bordwell notes about art film in general—imagery and narration to announce that "life is more complex than art can ever be, and...the only way to respect this complexity is to leave causes dangling and questions unanswered" (2003: 43). More specifically, New Hollywood cinema created a window into the abyss of an American society in political turmoil. As established values lost legitimacy in light of America's war in Vietnam and the spread of violence, racism and protest in major cities like New York, Chicago and Washington, D.C., in the 1960s, New Hollywood filmmakers found new ways to look at the processes, decisions and rationalizations that go into the institution of a social order. For this reason, Jonathan Kirshner (2012) states that New Hollywood was truly an "adult" cinema. It was in this brief period that we found, in mainstream American filmmaking, "characters with morally complex choices, not necessarily between right and wrong, but made by imperfect people trying to find the best alternative from the menu of compromised choices that circumstances have made available to them" (Kirshner 2012: 21).

Unfortunately, New Hollywood's politics and aesthetics were brief exceptions to the general rules of Hollywood cinema. Up until the birth of New Hollywood, the more than thirty-year tenure of the Hays Production Code Administration (PCA) had 
helped to transform Hollywood's ideology of entertainment into a formal quality of its cinema. If the PCA's official line was that "movies were entertainment, not vehicles for political pontification or controversy," major studios could sabotage filmmaking to make cinematic style mirror their ideology (Langford 2010: 1949). Hollywood cinema since the early 1980s can be seen as part of a contemporary period in which Hollywood's major firms have reasserted their power by once again widening the gap between filmmaker and audience. Indeed, the transformation of auteurism to commercial auteurism (Corrigan 2003) and the continual emphasis on blockbuster and high-concept cinema since the 1980s (Wyatt 1994; Cucco 2009) both reveal how the libido formandi of New Hollywood filmmakers won the battle but lost the war in a rigid system of contract negotiation that involves filmmakers, writing and directing guilds, agents, producers and, most significantly, dominant studios that monopolize film distribution (Bach 1985; Wasko 2003).

As a theoretical substitute to covering the history of Hollywood cinema in more detail, we can address questions of aesthetics and social signification with the addition of our second concept: capitalization. As a ritual of instrumental calculation, capitalization explains why major film-entertainment firms not only sabotage the distribution of film stock but also attempt to sabotage the creativity of filmmaking. Capitalists are forward-looking, and capitalization is the discounting of expected future earnings to present prices. ${ }^{6}$ What is capitalized is the "income stream" that is attached to an object through ownership:

The capital value of a business concern at any given time, its purchase value as a going concern, is measured by the capitalized value of its presumptive earnings; which is a question of its presumptive earning-capacity and of the rate or co-efficient of capitalization currently accepted at the time; and the second of these two factors is intimately related to the rate of discount ruling at the time. (Veblen 2004: 219)

Capitalists calculate how expected earnings will eventually translate into actual earnings, what risk premium they should factor in and what should be considered the normal rate of return. Importantly, none of these things-expectations about future earnings, risk and the normal rate of return-are extra-social. Capitalists must survey the state of society to know which investments are "good" for business, in comparison to investments the average capitalist would call "risky." Moreover, the "eye of capitalization" looks everywhere (Nitzan and Bichler 2009: 107). The entire order of society, from its institutions to its communities to its individuals, factors into a formula that is ultimately concerned with society's nomos:

Capitalists routinely discount [to present prices] human life, including its genetic code and social habits; they discount organized institutions from education and entertainment to religion and the law; they discount voluntary social networks; they discount urban violence, civil war and interna- 
tional conflict; they even discount the environmental future of humanity. (Nitzan and Bichler 2009: 107)

Since capitalization is forward-looking, the calculated expectations of the Hollywood film business concern the future of mass culture. Expected future earnings are discounted to present prices according to perceptions about the social-historical state of pleasure. For example, Time Warner, the owner of Warner Bros. Studio, lists social factors relating to its investment in filmed entertainment and leisure time under capitalism:

[Time Warner] must respond to recent and future changes in technology and consumer behaviour to remain competitive and continue to increase its revenues.... [Time Warner] faces risks relating to increasing competition for the leisure and entertainment time and discretionary spending of consumers, which has intensified in part due to technological developments and changes in consumer behaviour.... The popularity of [Time Warner's] content is difficult to predict, can change rapidly and could lead to fluctuations in the Company's revenues, and low public acceptance of the Company's content may adversely affect its results of operations. (Time Warner 2011: 13)

This "public acceptance of content" is important. If a film property is to be valued as an asset, its form and content must be evaluated—even before the film is made-in light of established social significations (Vogel 2011: 99-106). For example, on account of its style and subject matter, a film property may lose its relevance (that is, its pecuniary value as property) as social meaning changes with the passage of time:

War epics, for instance, might be very popular with the public during certain periods but very unpopular during others. Some humour in films is timeless; some is so terribly topical that within a few years audiences may not understand it. In addition, because everything from hair and clothing styles to cars to moral attitudes changes gradually over time, the cumulative effects of these changes can make movies from only two decades ago seem rather quaint. (Vogel 2011: 101)

In fact, a PricewaterhouseCoopers report can give us a sense of how a dynamic shift in what is considered funny or frightening can create real financial problems for those who are on the hook for the costs of a film. A change in the meaning of cinema can cause a pre-release write-down, which happens when the costs of a film become larger than the film's future expected earnings. Of the five examples of what can cause a write-down of future expectations, four of them relate to the social relations that envelop film production:

"Market conditions for the film that have changed significantly due to timing or other economic conditions;" 
"Screening, marketing, or other similar activities that suggest the performance of the film will be significantly different from previous expectations;"

"A significant change to the film's release plan and strategy;" and,

"Other observable market conditions, such as those associated with recent performance of similar films.” (PricewaterhouseCoopers 2009: 26)

This description of capitalization should not suggest that Hollywood, or any other capitalist firm, is trying to predict perfectly the flux of social-historical time. Rather, just as past institutions persisted on account of their ability to repress historical alternatives, Hollywood firms use their mode of power-their ability to sabotage industry with their rights of ownership - to attempt to harden the magma of significations that is relevant to investment in mass culture. Strategic sabotage is used to predetermine, as best as possible, the place of new creation in an instituted field of social significations. Some film projects, on account of their subject matter or style, can be effectively withheld from the market because no major firm will purchase the rights to distribute them. A film can be financed but also held to a contract that stipulates conditions about form, content, budget, cast, crew and so on. And if the business interest is still skeptical about its investment in potentially chaotic artistic creativity, the right of film ownership includes the right of "final cut," that is, the right to modify a film before it is released but after the director presents his or her final version. ${ }^{7}$

This right of final cut has, in the contemporary era, been a very effective means of sabotage. This specific right of ownership allows firms to leverage the American copyright system against filmmakers: ever since the inclusion of cinematic art in American copyright law, the rights of cinematic expression have almost always gone to the film producer, the distributor or both. And unlike in European copyright law, American filmmakers are not perceived to naturally possess "moral rights," which give original creators (filmmakers) an inalienable claim over how their art is expressed (Salokannel 2003; Decherney 2012).

Therefore, unless a filmmaker lives on the margins of independent film for the express purpose of trading many financing opportunities for more creative control, it is rare for directors or screenwriters to retain authorial rights in mainstream American cinema. Film production creates a product, a film, but the technological capacity to alter, edit, re-arrange or add to any film that is ostensibly completed can be abused by the business interests that own the copyright. Phil Alden Robinson, screenwriter, director and a representative for the Writers Guild of America, shared these feelings at a 1990 United States Congressional Hearing before the Subcommittee on Courts, Intellectual Property and the Administration of Justice:

To have even a chance of [producing a film] is the prime reason we create. But to go through all that and then to have somebody who did not put any of his sweat and tears and passion, much less a big chunk of his life into 
it, turn around and say, "Hey, pal, I own this and I think it would be better if we painted it green or cut off the ending or put in some rock music, or slapped in some nudity or lopped off the beginning," for someone to do that is the ultimate degradation, discouragement, insult, crime. It is a moral crime, not just against the creators, but against the people for whom that work was intended because they will not get to see it the way it was meant to be seen. So, instead of being moved by an artist who put part of his life into this, they will be ripped off by a merchant who gave it maybe 5 minutes of thought. (Robinson 1990: 197)

\section{Back to Castoriadis:The Need for Cultural Praxis}

In the sphere of film, Hollywood's power over creation represses what Castoriadis thinks autonomous democratic societies can affirm with their art: "The fact that brute reality is not fixed, but bears within it immense interstices which allow of movement, assembling, alteration, division; and the fact, too, that man is able to insert himself as a real cause in the flux of reality" (Castoriadis 1984b: 240). Thus the capitalist logic behind the Hollywood film business casts a large shadow over the possibilities of cultural praxis. The novelty and indeterminacy of social-historical creation should be seen as the vitamin of a cultural project, rather than its allergen: "When an artist begins a work, and even when an author begins a theoretical book, he both does and does not know what he is going to say-even less does he know what that which he will say will actually mean" (Castoriadis 1998: 74).

The power of autonomous creation is a threat to the instrumental activity of investing in images and symbols that are crystallizations of social meaning at particular moments in time. Again, extreme shifts in the magma of significations does not undermine cinema as a cultural-political activity. But it does undermine business interests that capitalize and sabotage cinema on the assumption that film production, distribution and exhibition are, primarily, capitalist techniques. Perceived as a process of technique - which Castoriadis explicitly distinguishes from praxis- the capitalist control of cinema falls apart when the mean-ends relationship of cinema and an already-instituted social imaginary is obscure to the point of being nondeterminable. The threat of non-determinable creation does not mean that investors expect nothing but risk-free investments. Rather, from the perspective of investment, it means that creation needs to be determinable enough for a film project to be weighable and calculable, where any potential risk to pecuniary earnings can be included in the capitalization formula. ${ }^{8}$

Hollywood's power over filmmaking is not natural, nor is it eternal, but power over creativity is necessary if Hollywood is to persist as a capitalist institution. As a power institution that attempts to "foresee, control and manage" cultural creation, Hollywood is heteronomous to the degree that its business structure "refuses to be altered as an institution" (Castoriadis 1998:214). By means of capital investment in 
the current organization of cultural creation, the major filmed-entertainment firms of Hollywood help to foreclose the autonomy of the demos in contemporary culture.

\section{Toward an Alternative Mode of Artistic Institutionalization}

The critique of the Hollywood film business clearly reveals the degree to which the capitalization of art cannot also give expression to the cultural values affirmed by Castoriadis. The question remains, however: within the present historical context, what mode or form of artistic practice is potentially capable of affirming the democratic principles that structure Castoriadis's model of autonomy? We will not attempt to provide an answer to this question - and indeed, an answer would be impossible, given Castoriadis's insistence that a rejuvenation of the artistic spirit would require a radical social transformation aimed at society as a whole (1997d: 347). Rather, we will point toward a recent artistic intervention, in which one of the authors of this paper was a participant, which was consciously undertaken in light of Castoriadis's reflections on democratic self-organization. This intervention was not designed to challenge directly the power of capitalist institutions, let alone the Hollywood film business. It was also not meant to create a universally applicable model of artistic organization. On the contrary, this intervention simply attempted to structure itself according to a certain democratic logic that could be seen to affirm the aesthetic values of Castoriadis.

In the spring of 2011, Ana Barajas curated a group exhibition at the Justina M. Barnicke Gallery in Toronto entitled "It takes everyone to no one." According to the promotional material for the exhibition, the works displayed attempted to "question the validity and inner workings of art institutions, and, in some instances, suggest reshaping their structure and purpose"(Justina M. Barnicke Gallery 2011). Of particular relevance was the work Cultural (de)Center for a Precarious Century, made by Rodrigo Hernandez-Gomez with the assistance of Dax Morrison and Chris Holman. This work created a non-permanent and non-virtual cultural space that aspired, through democratic interrogation, to sponsor artistic practices that aim to rejuvenate the relationship between art and the demos.

The starting point for the artists was their perception of the inadequacies of the formal structure of institutional spaces dedicated to displaying and supporting artistic works in the Canadian context, as reflected, for example, in the typical institutional charter of incorporation. Such charters produce rigid guidelines regarding the nature of the activities to be undertaken within an institution, as well as regarding the official status of artists, spectators, sponsors, administrators and so on. Castoriadis once noted that "nobody seems to notice that the very idea of painting for museums raises a host of questions" (1991a: 232).

It was precisely some of these questions on which the Cultural (de)Center for a Precarious Century artists attempted to reflect. Their goal was to imagine the 
construction of an alternative space, one capable of blurring or complicating the distinctions taken for granted by the typical museum or gallery, and of reflecting more adequately the understanding of democratic culture affirmed by individuals such as Castoriadis. In order to give a form to this goal, the artists first attempted to draft an alternative institutional charter, outlining their thoughts on the nature of culture, artistic production and artistic appropriation. The generative product of the charter was an institution dubbed the Cultural (de)Center, thus described by Hernandez-Gomez:

The (de)Center is already perhaps a statement on the need for new organizational structures that can allow for the emergence of unexpected cultural forms. We do not know what these forms are but we know that a different approach to the "administration" of cultural things will most likely result in other forms of collective expression.... Our project is first to work the ground for the possibility of new forms to emerge. (Rodrigo HernandezGomez, personal communication with the authors, December 11, 2011)

The (de)Center's charter begins with a set of brief reflections on the category of culture most generally, which is considered in the widest possible sense as a "concept that refers to certain natural-historical qualities of shared human activity," and which "both institutes a representation of and reconstitutes this activity" (Cultural (de)Center for a Precarious Century 2012). Crucially, the charter considers culture a form of "creative collective-activity" whose subjects are not restricted to a specialized set of individual technical producers, but are rather seen as part of a sphere in which all social actors participate in one way or another. Via such participation, the content of culture is continually reworked in such a way that culture may be conceived of as both "self-generation and self-alteration" (Cultural (de)Center for a Precarious Century 2012).

In keeping with what Castoriadis might refer to as the anonymous-collective orientation of cultural activity, self-alteration is associated not simply with the generation of specific artistic artifacts in the narrow sense, but rather with the generation "of a social world, of new modes of doing and being" (Cultural (de)Center for a Precarious Century 2012). That said, the (de)Center's specific contribution to cultural production would be realized through sponsoring specific projects that affirm the creative nature of individuals, the production of the (de)Center's charter being the first such project. There would not, however, be predetermined boundaries regarding the form or content of the projects to be sponsored:

The cultural production of the organization will manifest itself within distinct spheres, not being limited or restricted to already circumscribed spaces of presentation. Projects will occur in a variety of social contexts, and shall not be contained permanently within any traditional models of museum or exhibition space, whether physical or virtual. (Cultural (de)Center for a Precarious Century 2012) 
What is particularly significant about the (de)Center from the standpoint of Castoriadis's political thought is the way in which it approaches the issue of decisionmaking within the organization. We know that for Castoriadis it is impossible to separate the issues of autonomy in culture and politics: "The overcoming of the crisis of culture and the overcoming of the political crisis are absolutely inseparable" (1991a: 240). Specifically, a community capable of reflective commonality in aesthetic judgment is one that positively cathects new substantive values, which are themselves dependent on and nurtured by a change in existing political modes and orders. This relation is explicitly affirmed in the (de)Center's charter:

The institutional or organizational structure of the association shall reflect the model of culture that the association wishes to affirm. Therefore, it must be organized firstly so that it is open to the possibility of its own interrogation via the democratic activity of its members. (Cultural (de)Center for a Precarious Century 2012)

The (de)Center's charter, like traditional museum charters, specifies the existence of an organizational board of directors, but unlike more conventional documents it identifies such a board with the totality of the organization's membership, achieved via self-selected participation. This board would collectively decide on the trajectory of the organization's activity, such as the sponsoring of specific artistic projects. Such "collective determination may be achieved through a variety of means, including but not limited to voting, debate, discussion, and persuasion" (Cultural (de)Center for a Precarious Century 2012).

Applying something like Castoriadis's model of democratic interaction in the aesthetic sphere, the (de)Center argues that artistic discussion can be seen as structurally similar to political discussion, not least because it is irreducible to formal or rational laws of understanding. Discussion, rather, must aim at overcoming disagreement for the purpose of initiating action, but such discussion is reasonable as opposed to rational, inasmuch as it does not take the form of "strict demonstration" (Castoriadis 1991b: 91). In short, the democratic decision-making undertaken within the organization is designed to further nurture and cultivate the values that are necessary to the overall institution of autonomous social being. The point is to reaffirm values of autonomy and create a new cultural milieu, which is required for the perception of what Castoriadis calls the shock of aesthetic reception. In contrast to the capitalist interests of Hollywood, which purposefully sabotage the relationship between filmmaker and consumer, the Cultural (de)Center looks to re-establish the relationship between artist and public, via the open interrogation and stimulation of works via collective decision-making. In the final instance, the Cultural (de)Center attempts to initiate an education for democracy via a specific form of institutional practice, thus arousing those critical faculties necessary for autonomous aesthetic creation and reception. 


\section{Notes}

1. For Castoriadis, every society, through the deployment of social-imaginary significations embodied in its complex of norms, values and institutions, articulates an imaginary world that defines the range of the meaningful and the possible for it specifically. Here, 'imaginary' obviously does not signify the 'fictive,' the 'illusory,' the 'specular,' but rather the positing of new forms. This positing is not determined but rather determining; it is an unmotivated positing that no causal functional, or even rational explanation can account for" (Castoriadis 1997a: 84). What defines the specificity of the democratic society is that it is organized such that it is able to call into question its own existing institutions and its own existing social imaginary significations.

2. The major film distributors of Hollywood are: Disney, 20th Century-Fox (News Corp), NBC Universal (Comcast/GE), Columbia (Sony), Paramount (Viacom) and Warner Bros. (Time Warner). The parent corporations are in parentheses. These six firms also constitute the Motion Pictures Association of America.

3. All of their work is available online, on their website: http://bnarchives.yorku.ca.

4. After Marx, Nitzan and Bichler's research project dialogues with the works of Paul A. Baran and Paul M. Sweezy (Baran and Sweezy 1966), Stephen A. Marglin (Marglin 1974) and Mancur Olson (Olson 1982). However, we do not have the space to elaborate the important differences between the capital-as-power theory and other approaches that acknowledge the role of monopoly power in contemporary capitalism. The primary difference regards the nature of capital and whether capitalist power is or is not a measure of material productivity, for example, utility or labour-time. For Nitzan and Bichler's critique of both neo-classical and Marxist versions of monopoly power, see Nitzan and Bichler 2009.

5. For an application of the capital-as-power approach to art in general, see Suhail and Phillips 2012.

6. For a concise anthropology of capitalization, see Nitzan and Bichler 2009, 147-66.

7. For first-hand accounts of business versus industry in Hollywood, see Powdermaker 1950; Bach 1985; Dunne 1998; and Ross 2002.

8. As Peter L. Bernstein emphasizes in his history of risk (Bernstein 1998), the study of probability and Fortuna is allergic to chaos, not risk. A so-called "risky" investment is not so problematic if the valuation of an asset is risk-adjusted. For more on the role of risk in the capitalization of Hollywood cinema, see McMahon 2013.

\section{References}

Adorno, Theodor. 2004. Free Time. In The Culture Industry: Selected Essays on Mass Culture, edited by J. M. Bernstein, 187-97. New York: Routledge.

Bach, Steven. 1985. Final Cut: Dreams and Disaster in the Making of Heaven's Gate. New York: William Morrow.

Baran, Paul A., and Paul M. Sweezy. 1966. Monopoly Capital: An Essay on the American Economic and Social Order. New York: Monthly Review Press. 
Benjamin, Walter. 1968. The Work of Art in the Age of Mechanical Reproduction. In Illuminations, edited by Hannah Arendt, 217-52. New York: Schocken Books.

Bernstein, Peter L. 1998. Against the Gods: The Remarkable Story of Risk. New York: John Wiley \& Sons.

Bichler, Shimshon, and Jonathan Nitzan. 2012. The Asymptotes of Power. Real-World Economics Review 60(June): 18-53.

- 2014. No Way Out: Crime, Punishment and the Capitalization of Power. Crime, Law and Social Change 61(3): 251-71.

Bloch, Ernst. 1988. Ideas as Transformed Material in Human Minds, or Problems of an Ideological Superstructure (Cultural Heritage). In The Utopian Function of Art and Literature: Selected Essays, translated by Jack Zipes and Frank Mecklenburg, 18-70. Cambridge, MA: MIT Press.

Bordwell, David. 2003. Authorship and Narration in Art Cinema. In Film and Authorship, edited by Virginia Wright Wexman, 42-49. New Brunswick, NJ: Rutgers University Press.

Castoriadis, Cornelius. 1984a. Value, Equality, Justice, Politics: From Marx to Aristotle and From Aristotle to Ourselves. In Crossroads in the Labyrinth, translated by Kate Soper and Martin H. Ryle, 260-339. Cambridge, MA: MIT Press.

. 1984b. Technique. In Crossroads in the Labyrinth, translated by Kate Soper and Martin H. Ryle, 229-59. Cambridge, MA: MIT Press.

1991a. The Crisis of Culture and the State. In Philosophy, Politics, Autonomy: Essays in Political Philosophy, edited by David Ames Curtis, 219-42. New York: Oxford University Press.

1991b. The Greek Polis and the Creation of Democracy. In Philosophy, Politics, Autonomy, edited and translated by David Ames Curtis, 81-123. New York: Oxford University Press.

.1991c. The Nature and Value of Equality. In Philosophy, Politics, Autonomy, edited and translated by David Ames Curtis, 124-42. New York: Oxford University Press.

- 1991d. Power, Politics, Autonomy. In Philosophy, Politics, Autonomy, edited by David Ames Curtis, 143-74. New York: Oxford University Press.

-1993a. Social Transformation and Cultural Creation. In Political and Social Writings, Volume 3, 1961-1979: Recommencing the Revolution: From Socialism to the Autonomous Society, edited by David Ames Curtis, 300-13. Minneapolis: University of Minnesota Press.

1993b. The Crisis of Modern Society. In Political and Social Writings, Volume 3, 1961-1979: Recommencing the Revolution: From Socialism to the Autonomous Society, edited and translated by David Ames Curtis, 106-17. Minneapolis: University of Minnesota Press.

1995. The Dilapidation of the West. Thesis Eleven 41(1): 94-114.

. 1997a. The Greek and the Modern Political Imaginary. In World in Fragments: Writings on Politics, Society, Psychoanalysis, and the Imagination, edited and translated by David Ames Curtis, 84-107. Stanford, CA: Stanford University Press. 
1997b. The Imaginary: Creation in the Social-Historical Domain. In World in Fragments: Writings on Politics, Society, Psychoanalysis, and the Imagination, edited and translated by David Ames Curtis, 3-18. Stanford, CA: Stanford University Press.

.1997c. The Logic of Magmas and the Question of Autonomy. In The Castoriadis Reader, edited and translated by David Ames Curtis, 290-318. Oxford: Blackwell Publishing.

1997d. Culture in a Democratic Society. In The Castoriadis Reader, edited and translated by David Ames Curtis, 338-48. Oxford: Blackwell Publishing.

-1997e. The Ethicists' New Clothes. In World in Fragments: Writings on Politics, Society, Psychoanalysis, and the Imagination, edited and translated by David Ames Curtis, 108-22. Stanford, CA: Stanford University Press.

. 1998. The Imaginary Institution of Society, translated by Kathleen Blamey. Cambridge, Massachusetts: MIT Press.

2007a. Aeschylean Anthropogony and Sophoclean Self-Creation of Anthrōpos. In Figures of the Thinkable, translated by Helen Arnold, 1-20. Stanford, CA: Stanford University Press.

2007b. Notes on Some Poetic Resources. In Figures of the Thinkable, translated by Helen Arnold, 21-44. Stanford, CA: Stanford University Press.

Cochrane, D.T. 2011. Castoriadis, Veblen, and the "Power Theory of Capital." In Depoliticization: The Political Imaginary of Global Capitalism, edited by J.F. Humphrey and Ingerid S. Straume, 89-123. Copenhagen: Aarhus University Press.

Corrigan, Timothy. 2003. The Commerce of Auteurism. In Film and Authorship, edited by Virginia Wright Wexman, 96-111. New Brunswick, NJ: Rutgers University Press.

Cucco, Marco. 2009. The Promise Is Great: The Blockbuster and the Hollywood Economy. Media, Culture E' Society 31(2): 215-30.

Cultural (de)Center for a Precarious Century. 2012. Act of Institution. Cultural (de)Center for a Precarious Century. http://culturaldecenter.net/act-of-institution/.

Decherney, Peter. 2012. Hollywood's Copyright Wars: From Edison to the Internet. New York: Columbia University Press.

Dunne, John Gregory. 1998. The Studio. New York: Vintage Books.

Justina M. Barnicke Gallery. 20111. It takes everyone to know no one. http://www. jmbgallery.ca/ExPastEveryone.html.

Kirshner, Jonathan. 2012. Hollywood's Last Golden Age: Politics, Society, and the Seventies Film in America. Ithaca, NY: Cornell University Press.

Langford, Barry. 2010. Post-Classical Hollywood: Film Industry, Style and Ideology Since 1945. Edinburgh: Edinburgh University Press.

Litman, Barry Russell. 1998. The Motion Picture Mega-Industry. Boston, MA: Allyn and Bacon.

Marglin, Stephen A. 1974. What Do Bosses Do? The Origins and Functions of Hierarchy in Capitalist Production. Review of Radical Political Economics 6(2): 60-112.

Marx, Karl. 1990. Capital: A Critique of Political Economy, translated by Ben Fowkes. Vol. 1. New York: Penguin Books. 
McMahon, James. 2013. The Rise of a Confident Hollywood: Risk and the Capitalization of Cinema. Review of Capital as Power 1(1): 23-40.

Motion Picture Association of America, Inc. 2011. Public Performance Law. http://www. mpaa.org/contentprotection/public-performance-law.

Nitzan, Jonathan, and Shimshon Bichler. 2000. Capital Accumulation: Breaking the Dualism of "Economics" and "Politics." In Global Political Economy: Contemporary Theories, edited by Ronen Palan, 67-88. New York: Routledge.

- 2009. Capital as Power: A Study of Order and Creorder. New York: Routledge.

Olson, Mancur. 1982. The Rise and Decline of Nations: Economic Growth, Stagflation, and Social Rigidities. New Haven: Yale University Press.

Powdermaker, Hortense. 1950. Hollywood the Dream Factory: An Anthropologist Looks at the Movie-Makers. Boston, MA: Little, Brown and Company.

PricewaterhouseCoopers. 2009. Filmed Entertainment: Cost Capitalization, Amortization, and Impairment. Perspectives: Entertainment, Media \& Communications Industry. New York: PricewaterhouseCoopers.

Robinson, Phil Alden. 1990. Moral Rights and the Motion Picture Industry. Los Angeles: U.S. Government Printing Office.

Ross, Lillian. 2002. Picture. Cambridge, MA: De Capo Press.

Salokannel, Marjut. 2003. Cinema in Search of Its Authors: On the Notion of Film Authorship in Legal Discourse. In Film and Authorship, edited by Virginia Wright Wexman, 152-78. New Brunswick, NJ: Rutgers University Press.

Sedgwick, John, and Michael Pokorny. 2005. The Characteristics of Film as a Commodity. In An Economic History of Film, edited by John Sedgwick and Michael Pokorny, 6-23.

New York: Routledge.

Suhail, Malik, and Andrea Phillips. 2012. Tainted Love: Art's Ethos and Capitalization. In Contemporary Art and Its Commercial Markets: A Report on Current Conditions and Future Scenarios, edited by Maria Lind and Olav Velthuis, 209-40. Berlin: Sternberg Press.

Time Warner. 2011. Form 10-Kfor the Year Ended December 31, 2011. Annual Report.

Veblen, Thorstein. 2004. Absentee Ownership: Business Enterprise in Recent Times: The Case of America. New Brunswick, NJ: Transaction Publishers.

- 2006a. On the Nature of Capital: I. The Productivity of Capital Goods. In The Place of Science in Modern Civilization: And Other Essays, 324-51. New Brunswick, NJ: Transaction Publishers.

. 2006b. On the Nature of Capital: II. Investment, Intangible Assets, and the Pecuniary Magnate. In The Place of Science in Modern Civilization: And Other Essays, 352-86. New Brunswick, NJ: Transaction Publishers.

Vogel, Harold L. 2011. Entertainment Industry Economics: A Guide for Financial Analysis. 8th ed. New York: Cambridge University Press.

Wasko, Janet. 2003. How Hollywood Works. London: SAGE.

Wu, Tim. 2010. The Master Switch: The Rise and Fall of Information Empires. New York: Alfred A. Knopf. 
Wyatt, Justin. 1994. High Concept: Movies and Marketing in Hollywood. Austin: University of Texas Press. 